\title{
IMPORTANT BIRD AREAS OF SASKATCHEWAN
}

JOSEF K. SCHMUTZ, Important Bird Areas Program, c/o Centre for Studies in Agriculture, Law and Environment (CSALE), University of Saskatchewan, 51 Campus Drive, Saskatoon, SK S7N 5A8E-mail: joe.schmutz@usask.ca

\section{Introduction}

The Important Bird Areas (IBA) program is coordinated by BirdLife International, a partnership of non-governmental organizations in over 100 countries that seeks to identify and conserve sites important to bird species worldwide. Through the protection of birds and habitats, it also promotes the conservation of the world's biodiversity.

The IBA concept arose from studies on conservation needs and approaches conducted by BirdLife International and the International Wetlands Research Bureau on behalf of the Commission of the European Community and the Council of Europe. This work culminated in the 1989 publication Important Bird Areas of Europe and marked the beginning of the IBA program. IBA programs now exist in Europe, Africa, the Middle East, Asia, and the Americas - which includes Canada, Mexico, the United States and 17 countries in Central and South America.

In Canada, BirdLife formed a partnership with the Canadian Nature Federation and Bird Studies Canada! Bird Studies Canada is a non-profit conservation organization whose data, gathered by volunteers and professionals, was used for IBA site identification and designation. The Canadian Nature Federation facilitates conservation planning and implementation, working with its provincial partners. In Saskatchewan, IBA is delivered by the Canadian Nature Federation's affiliate, Nature Saskatchewan. Nature
Saskatchewan hired the author as community conservation planner, assisted in securing additional matching funds, participated in meetings with the communities and published the community conservation plans.

Goals of the Canadian IBA program are to:

- identify a network of sites that conserve the natural diversity of Canadian bird species and are critical to the long-term viability of naturally occurring bird populations;

- determine the type of protection or stewardship required for each site, and ensure the conservation of sites through partnerships of local stakeholders who participate in development and implementation of appropriate on-theground conservation plans; and

- establish ongoing local involvement in site protection and monitoring.

The emphasis on local community participation in protecting and monitoring conservation areas is a priority in the IBA program. It is based on the belief that meaningful and long-term conservation success depends on the participation of the local community. In this communityconservation approach, the aspirations of the local community are given considerable weight. This approach is rooted in Africa "... where its practice ranges from park outreach programmes in East Africa to southern Africa's radical policies to give back to communities the rights to use and benefit from the wildlife on their land. The latter, in particular, have contributed 


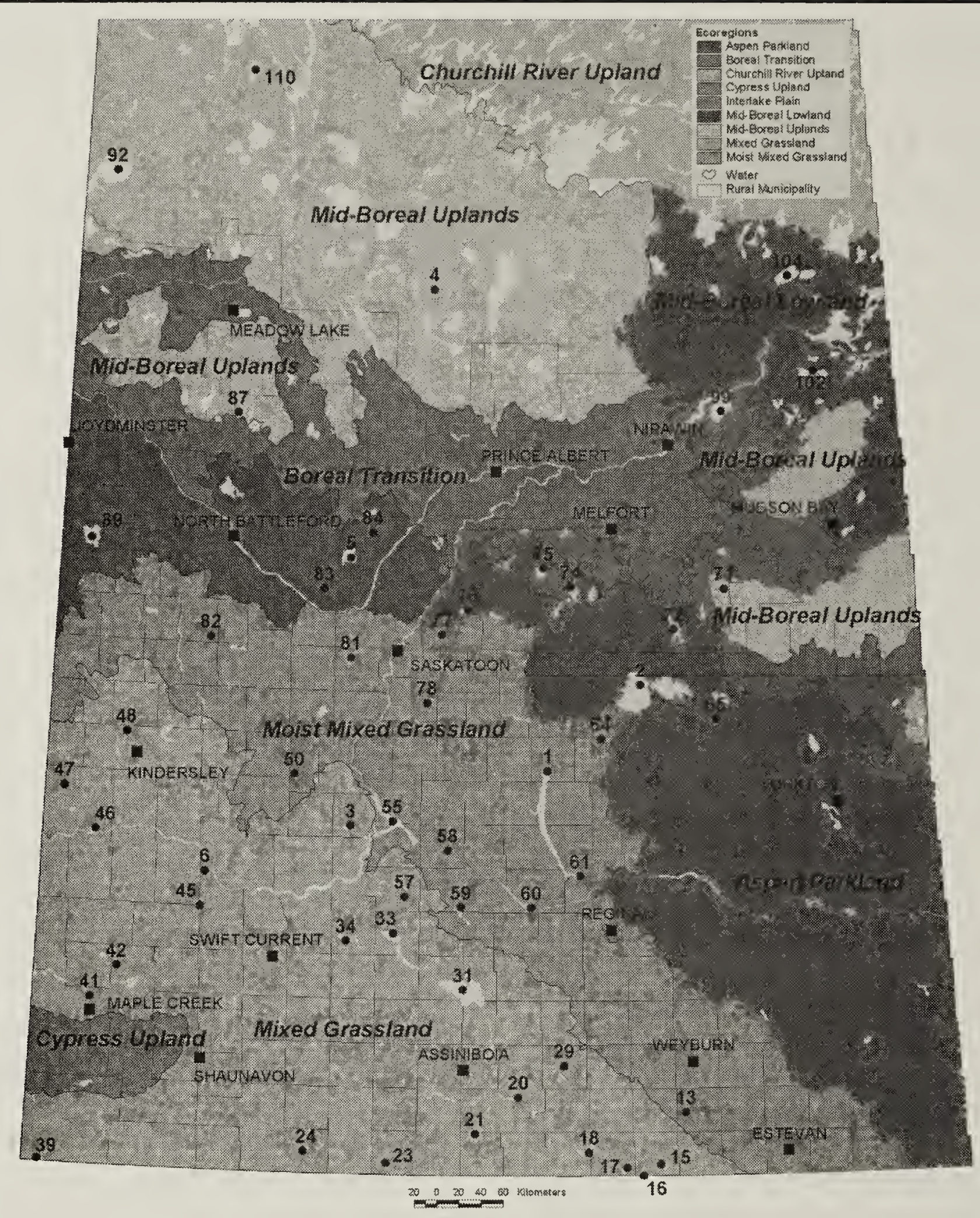

Important Bird Areas

1 - Last Mountain Lake NWA

2 - Quill Lakes

3 - Luck Lake

4 - Lavalleé Lake

5 - Redberry Lake

6 - Galloway and Miry Bay

13 - Colgate Prairie

15. Sandoff Lake

16 - Alkali Lake

17 - Coteau Lakes

18 - Big Muddy Lake (and surroundings)

20 - Willow Bunch Lake

21 - Fife Lake

23- Grasslands National Park (east)

24 - Grasslands National Park (west)

23. Dryborofourn Lake

31 - Old Wives-Frederick Lakes

33 - Chaplin Lake

34 - Reed Lake

39 - Govenlock-Nashlyn-Battle Creek Grasslands

41 - Maple Creek Grasslands

42 - Bigstick Lake Plain

45 - Cabri Area

46 - S Saskatchewan River (Empress to Lancer Ferry)

47 - Mantario Hills

48 - Kindersley-Elna

50 - Barber Lake

55 - East Lake Diefenbaker

57 - Paysen Williams/Kettlehut Lakes

58 - Eyebrow Lake

59 - Pelican Lake

60 - Nicolle Flats

61 - Valeport Marsh

G4 - Kutawagan Lake

65 - Foam Lake

71 - Greenwater Lake Provincial Park
72 - Ponass Lake

74 - Lake Lenore

75 - Basin and Middle Lake

76 - Buffer Lake

77 - Porter Lake

78 - Blackstrap Coulee

81 - Rice Lake

82 - Landis Lake

83 - Radisson Lake

84 - Blaine Lakes

87 - Midnight Lake

89 - Manitou Lake Area

92 - Primrose Lake

99 - Tobin Lake

102 - Cumberland Marshes

104 - Suggilake

110 - Kazan Lake

Fig. 1. Location of 53 Important Bird Areas in 8 ecoregions in Saskatchewan. Numbers are those assigned to each $I B A$. 
significantly to the emerging idea that conservation should contribute to basic human needs rather than conflict with them. This radical revision of a paradigm built on 'fortress conservation' is already incorporated into key international conventions..."2

\section{Site Selection}

IBAs are identified as sites that regularly hold significant numbers of one or more of the following: an endangered, threatened, or vulnerable species; endemic species, or species with restricted ranges; an assemblage of species largely restricted to a biome; or sites where birds concentrate in significant numbers during the breeding season, in winter, or during migration. As with other international programs that designate areas for conservation purposes, IBA uses what is called the $1 \%$ rule. For a site to qualify under the program, it has to support at least $1 \%$ of the national or global bird population of that species to be nationally or globally significant.

The site-based approach is used because certain species depend on particular areas for all or part of the year. However, some species cannot meaningfully be protected in this way and a landscape- or widermanagement approach is necessary for them. Here, IBA can complement other approaches such as Partners in Flight and also local initiatives.

\section{IBAs in Saskatchewan}

Saskatchewan's Important Bird Areas program was launched with a workshop in Saskatoon on 22 October 1997 when naturalists and birders met to nominate areas in the province that are important for birds. Of the 123 sites nominated, 53 survived program review and were designated Saskatchewan IBAs in 2001 (Figure 1 and Table 1).

An extensive set of published articles and unpublished reports was reviewed to arrive at these designations. Data sources are listed by site on the IBA web site'. The list of areas alone is evidence of the diversity of birds residing in functioning ecosystems in Saskatchewan during all or part of a year, and provides a record for monitoring in the future. In the 53 sites, there are 82 species of birds that are important at least nationally, approximately one fifth of all bird species in Saskatchewan.

On 1 February 1999, a subset of 13 IBAs was selected by an advisory committee and conservation plans were completed for these in March 2002. A conservation plan is a 50-100 page document that describes the ecosystem of which the birds are a part, the area's land use, conservation needs and conservation opportunities as identified by community and other stakeholders.

Of the 13 sites for which conservation plans have been developed, two focus on grasslands (Govenlock, Nashlyn and Battle Creek IBA, and Colgate Prairie IBA), one on a marsh-lake-upland complex (Cumberland Marshes IBA), and the remainder on water bodies. For five lake IBAs, the adjacent upland is as important as the wetland in the ecology of IBA birds; for these areas the IBA has been expanded to include the entire watershed (Redberry, Chaplin, Old Wives and Reed lakes, and Manitou Lake area) or portions of watersheds.

Working with the local communities, IBA Saskatchewan has been involved in field trips with schools (Figure 2), and has supported local communities in their desire to protect vulnerable areas and species. For example, IBA Saskatchewan is collaborating with Saskatchewan Environment and the Prairie Farm Rehabilitation Administration in a study of silver sage communities in relation to a decline in Greater Sage Grouse in SW Saskatchewan. Projects are underway in the Wood River watershed to influence water quality and quantity for local people and birds at Chaplin and Old Wives lakes. A study has been completed by members of the Centre for Studies in Agriculture, Law and Environment that 
Table 1. IBAs in Saskatchewan showing their significance status ( $\mathrm{G}=\mathrm{Global}$, $\mathrm{C}=$ Continental, $\mathrm{N}=$ National) and the 82 bird species involved in classification. Numbers in bold are species for which the site received its status.

Site, Status

Bird species/groups (see key at bottom of this table)

Areas with conservation plans

Chaplin Lake, G 1, 4, 13, 51, 53, 55, 63, 65, 68, 70, 77, 81, C

Colgate Prairie, N 13, 25

Cumberland Marshes, G 3, 7, 15, 16, 19, 28, 44, 56, 58, 73, E

Galloway and Miry Bay, G 15, 33, 64, D, E

Govenlock-Nashlyn-Battle Creek Grasslands, N 12, 13, 25, 32, 52, 62

Luck Lake, G 27, 33, 35, 39, 40, 45, 59, 64, 72, 73, 79, 82, C, D, E

Manitou Lake Area, G 15, 15, 38, 51, 55, 56, 63, 70, C, E

Old Wives Lake, G

$\mathbf{1}, \mathbf{3}, 9, \mathbf{1 6}, 21,22,27,30,30,51,51,57, \mathbf{6 3}, \mathbf{6 5}, 68, \mathbf{7 0}, 73,75, \mathrm{~A}, \mathbf{C}, \mathbf{E}$ Quill Lakes, G

$1,1,3,4,8,23,25,35,37,40,51,55,64,65,68,70,77,79, \mathbf{C}, \mathbf{D}, \mathbf{E}$

Radisson Lake, G 51, 67, 73, 79, E

Redberry Lake, G 3, 5178

Reed Lake, G 1, 4, 16, 22, 27, 39, 48, 51, 53, 55, 56, 65, 70, 73, A, C, E

Sandoff Lake, N 51

\section{Additional areas}

Alkali Lake, N 22, 51

Barber Lake, G 16, 25, 38, 59, E

Basin and Middle Lakes, G 3, 9, 22, 51, C, E

Big Muddy Lake Area, C 6, 13, 25, 29, 51, 52, 62, 74, E

Bigstick Lake Plain, G 9, 13, 14, 24, 25, 27, 36, 51, 57, 81, E

Blackstrap Coulee, G 7, 11, 26, 27, 55, 70, 73, 75, A, E

Blaine Lakes, G 63, C

Buffer Lake, G 4, 35, 51, 55, 63, 65, 79, C

Cabri Area, N 13, 25, 44, 59, E

Coteau Lakes, N 51

Dryboro/Burn Lake, N 51

East Lake Diefenbaker, G 51, 75, E

Eyebrow Lake, N 1, 9, 17, 24, 25, 27, 28, 38, 60, 66, 69, 80, E

Fife Lake, C 5, 9, 13, 24, 51, 75

Foam Lake, N 39, 64, E

Grasslands National Park (east), N 13, 25, 32, 13, 20, 25, 29, 32, 46

Grasslands National Park (west), N 13, 20. 25, 29, 32, 46

Greenwater Lake Provincial Park, N 30, 71

Kazan Lake, G 3, 22, 30, 49

Kindersley-Elna, G 13, 25, E

Kutawagan Lake, G 33, 37, 47, 51, 73, E

Lake Lenore, G 3, 9, 9, 15, 22, 30, 51, 61, A, C, E

Landis Lake, G 1, 40, 50, 51, 55, 63, 70, C

Last Mountain Lake National Wildlife Area, G

$1,3,7,9,22,25,26, \mathbf{3 3}, \mathbf{3 9}, 40,40,41,45,51,55, \mathbf{6 4}, 65, \mathbf{7 0}, \mathbf{7 9}, \mathbf{8 0}, 81, \mathrm{~B}, \mathbf{D}, \mathbf{E}$ 
Lavalleé Lake, G 3, 22, A

Mantario Hills, C 15, 25, E

Maple Creek Grasslands, N 13, 25, 30, E

Midnight Lake, G 79

Nicolle Flats, N 3, 7, 9, 27, 30, 44, 56, E

Paysen/Kettlehut Lake, N 11, 21, 22, 24, 26, 27, 28, 48, 75

Pelican Lake, G 1, 3, 8, 45, 73, 75, 81, C, E

Ponass Lake, G 39, 64, E

Porter Lake, G 35

Primrose Lake, G 3, 14, 21, 22, 30, 34

Rice Lake, G 9, 15, 24, 27, A, D, E

South Saskatchewan River (Empress to Lancer Ferry), G

15, 25, 29, 31, 42, 51, 52, 54, 74, 76, E

Suggi Lake, G 3, 14, 21, 22, 30, 34, 57, A

Tobin Lake, G 3, 10, 57, 73

Valeport Marsh, G 2, 3, 15, 18, 30, 43, 43, 70, E

Willow Bunch Lake, G 51

Bird species: 1 American Avocet, 2 American Golden Plover, 3 American White Pelican, 4 Baird's Sandpiper, 5 Bank Swallow, 6 Black Rosy-Finch, 7 Black Tern, 8 Black-bellied Plover, 9 Black-crowned Night-Heron, 10 Bonaparte's Gull, 11 Bufflehead, 12 Bullock's Oriole, 13 Burrowing Owl, 14 California Gull, 15 Canada Goose, 16 Canvasback, 17 Cattle Egret, 18 Clark's Grebe, 19 Common Goldeneye, 20 Common Poorwill, 21 Common Tern, 22 Double-crested Cormorant, 23 Dowitcher, 24 Eared Grebe, 25 Ferruginous Hawk, 26 Forster's Tern, 27 Franklin's Gull, 28 Gadwall, 29 Golden Eagle, 30 Great Blue Heron, 31 Great Horned Owl, 32 Greater Sage-Grouse, 33 Greater Whitefronted Goose, 34 Herring Gull, 35 Hudsonian Godwit, 36 Lark Bunting, 37 Least Sandpiper, 38 Lesser Scaup, 39 Lesser Snow Goose, 40 Lesser Yellowlegs, 41 Loggerhead Shrike, 42 Long-billed Curlew, 43 Long-billed Dowitcher, 44 Mallard, 45 Marbled Godwit, 46 Mountain Plover, 47 Northern Pintail, 48 Northern Shoveler, 49 Osprey, 50 Pectoral Sandpiper, 51 Piping Plover, 52 Prairie Falcon, 53 Red Knot, 54 Red-headed Woodpecker, 55 Red-necked Phalarope, 56 Redhead, 57 Ring-billed Gull, 59 Ross's Goose, 60 Ruddy Duck, 61 Ruddy Turnstone, 62 Sage Thrasher, 63 Sanderling, 64 Sandhill Crane, 65 Semipalmated Sandpiper, 66 Short-billed Dowitcher, 67 Snow Goose, 68 Snowy Plover, 69 Spotted Sandpiper, 70 Stilt Sandpiper, 71 Trumpeter Swan, 72 Tufted Duck, 73 Tundra Swan, 74 Turkey Vulture, 75 Western Grebe, 76 Western Screech-Owl, 77 White-rumped Sandpiper, 78 White-winged Scoter, 79 Whooping Crane, 80 Willet (Western), 81 Wilson's Phalarope, 82 Yellow Rail.

Bird groups: A Colonial Waterbirds/Seabirds, B Landbird Concentrations, C Shorebirds, D Wading Birds (Herons, Cranes etc.), E Waterfowl. 


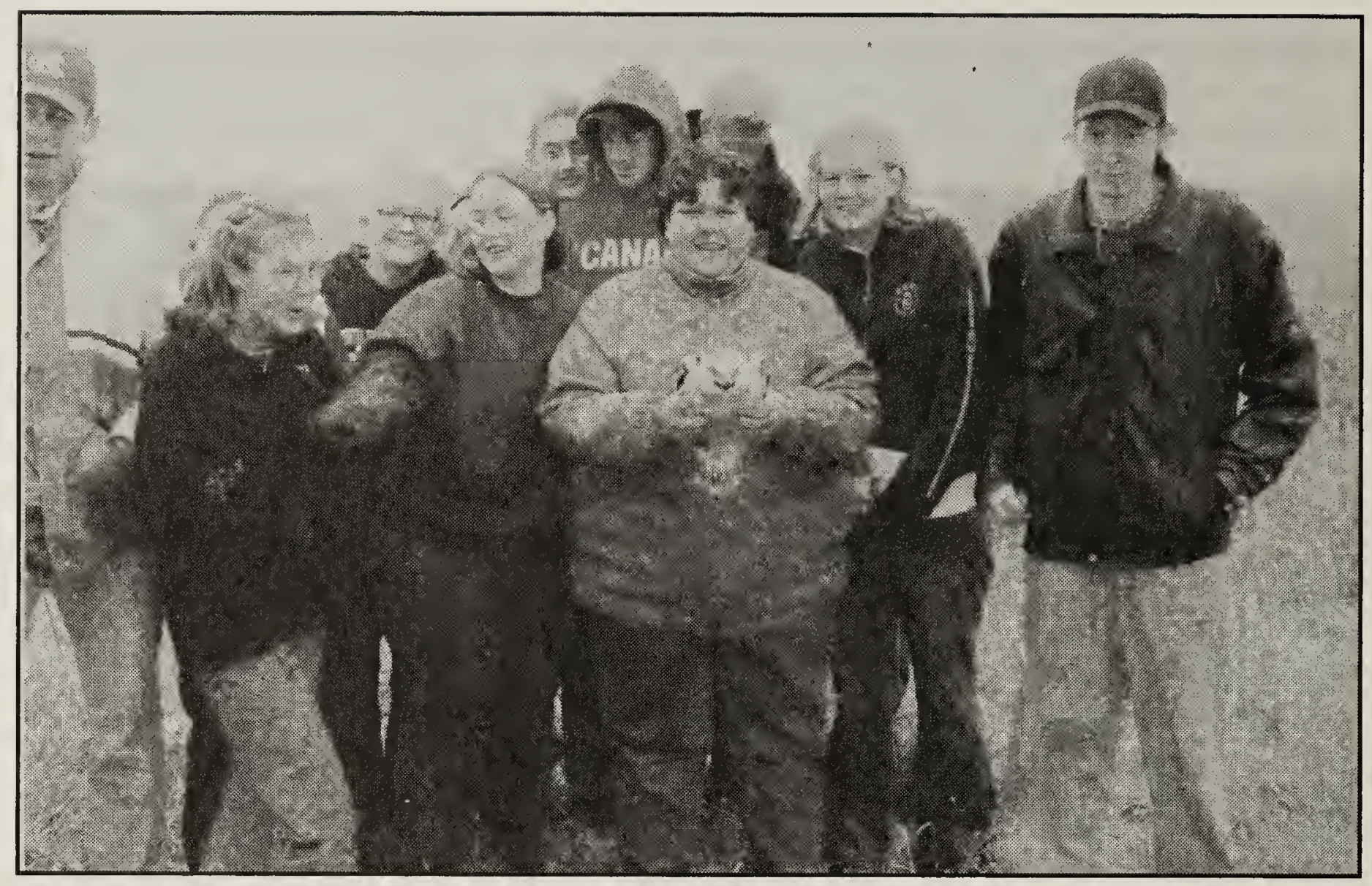

Fig. 2. Nestling Ferruginous Hawk encounters Consul Grade 11 \& 12 class on a field trip to Govenlock-Nashlyn-Battle Creek IBA on 13 June 2001 Joe Schmutz

examines the various legal mechanisms Saskatchewan communities use to influence resource use in and outside of IBAs. Because the projects are locally driven and ecosystem based, their sustainability- and community-oriented focus is often interdisciplinary.

The Canadian and Saskatchewan IBA program has now moved from site identification and conservation planning to project implementation. It is still possible to add new sites or develop new conservation plans under special circumstances, but such initiatives are now expected to come largely from provincial partners or local communities. The Canadian Nature Federation is maintaining a level of vigilance across all IBAs to identify potential threats and assist local communities in protecting the sites. Toward this end, the Federation has established a Community Action Fund to support local conservation action in recognized IBAs.

\section{Acknowledgements}

Margaret A. Skeel kindly provided comments on the manuscript. Darrel Cerkowniak of the Saskatchewan Land Resources Centre, University of Saskatchewan, drafted Figure 1. Robert Wapple and Alan R. Smith compiled the bird data for all nominated areas and this in turn was possible only because of many hours spent afield by amateur and professional biologists.

1. IMPORTANT BIRD AREAS OF CANADA web site. http://www.ibacanada.ca

2. HULME, D. AND M. MURPHREE, EDS. 2001. African wildlife and livelihoods: The promise and performance of community conservation. Heinemann, Portsmouth, N.H. 